\title{
DIASPORA AND IDENTITY IN THE SELECTED POEMS OF MEENA ALEXANDER
}

\author{
Pooja Kushwaha \\ Research Scholar \\ Department of English and M.E.L. University of Lucknow, \\ Lucknow, Uttar Pradesh, India.
}

\begin{abstract}
On the literary map of Indian women writings, Meena Alexander appears to be leading woman poetess. The question of identity is the most controversial issue in postcolonial time and literature and it can be regarded the most important because its crisis exists in all postcolonial communities. She negotiates with the issue of 'Diaspora' and 'Identity' in almost all her writings. Meena Alexander is always in an experiment on the issues of 'Diaspora' and 'Identity' in her creative oeuvre. This paper endeavors to explore her postcolonial journey and her views of making a home, a living one and a literary one, and an individual identity of her own through her literary and poetic creations.
\end{abstract}

Keywords- Diaspora, identity.

\section{INTRODUCTION}

In modern time, poetry has been become a source of instrument changes in the literature. Many people think that poetry seems to be pushed aside. It has lost its importance. During the last fifty years, there has been an outburst of Indian women's poetry in English published in India and abroad. The poetry of exile has acquired significant position in the realm of Indian English Poetry. The notion of identity has been problematized in an unprecedented manner in the multicultural modern society. The issue of identity and language are knit into the postcolonial fabric of American present. The contemporary women poets also reflect the beauty of nature. As they show in their poetry, that travels through symbol of past, places, childhood and social ironies of modern life.

Indian English writing is a colorful spectrum of poetry, drama and fiction. The Indian women poets often write in confessional mode such as sexuality, conflicts, love affairs, guilt, shame, ambition, childhood, memories of the past, rebellions and articulation of fractured self. Women poets have added new dimension to Indian poetry in English. Indian English Poetry represents the transition of India from the colonial to the post - independence period. Women poets have added new dimension to Indian English Poetry in English.
The new poetry has emerged as a new awareness. Modern Indian poetry finds one of its authentic voices in English. It is enriched by the experiences of Diaspora writers. It represents the complexity of Indian experience poetry. The women poets of Indian Diaspora have migrated to and settled in various countries like USA, Australia, Denmark, England and Germany. They are living in foreign country. The contribution of contemporary Indian women poets in English represent the range of their talent. The contemporary women poets show the Indian womanhood and emphasize on the search of identity. The new poets carry wounds in their hearts. New poets attempt to present human beings, their anguish and alienation from their roots. They have added new dimensions to Indian poetry in English. They aim to reveal human beings, their alienation and anguish.

The poetry of Diaspora women poets represent the tensions caused by their Indian psyche in the alien situation. Diaspora and search for identity have come to play a vital role in the contemporary literary and cultural criticism, especially in immigrant literature.

The aim of this article is to reflect the problems of immigrants in the migrated land such as rootlessness, question of language and identity, nostalgia, alienation, of belonging and not belonging and problems of living as a female body in immigrant situation. This study intends to develop an enquiry into variety of themes: violence, diasporic consciousness, racial experience, violence, and resistance, notion of lost language, subaltern voice, history and myth. The present study also attempts to explore that the poet also shows more subtle and complex insights about their societies. It will enhance the reader's understanding of her as a major poet of the Indian diaspora.

It is very important to mention that the present study is primarily concerned with analyzing some poems composed by Meena Alexander who is considered one of the prominent South Asian American migrant women writers. From a migrant perspective, the paper focusses on two recurrent themes in Alexander' writing: Diaspora and Identity. Hessa A. Alghadeer says in the article "Exploring Third space: Place and memory in Meena Alexander's memoir and poems": 


\section{International Journal of Engineering Applied Sciences and Technology, 2020 \\ Vol. 5, Issue 5, ISSN No. 2455-2143, Pages 100-104 \\ Published Online September 2020 in IJEAST (http://www.ijeast.com)}

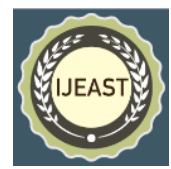

Straddling between cultures and countries, from India, through Sudan, England and America, is a poignant experience initiating multiplicity and dislocation in Alexander's past and present, and consequently reframing both her life and writing career. Against a backdrop of dissimilar geographical territories, Alexander depicts several migratory experiments to convey numerous literary languages expressions of the hybrid languages expressions of the hybrid condition. (86)

Meena Alexander is undoubtedly one of the foremost poets writing in English today. She was born in 1951 in Allahabad, raised in Kerala and Khartoum, educated in Sudan and Nottingham, UK, worked in Hyderabad and Delhi, India and settled in New York. She has received many awards such as Altruss International Award (1973), The New York State Foundation for the Arts Poetry Award (1999), and a PEN Open Book Award (2002, for Illiterate Heart). Alexander has established herself as a well- known Asian American poet in the United States. She has published several volumes of poetry. Currently she is a distinguished professor of English at Hunter College and the Graduate Center of the City University of New York. She represents migrant memories, separation, trauma, uprooting, exile and loneliness. Her literature have been widely published in magazines in the USA, UK and India.

She is a highly sensitive poet. Her poetry is a representation of Indian and immigrant experiences. Her poetry reflects the connection between two worlds and between memory and present experience. She is establishing herself on several fronts as a creative writer, as a child, as a woman and as an expatriate in America, exploring into the issue of ethnicity. The traumas of the search for an identity are recurrent themes in her poetry. She tries to define her Indian identity. G. Yamini writes in her article, "Nostalgia in Meena Alexander's Illiterate Heart":

The acute sense of loss and nostalgia is reflected in the creative output of Alexander. Her desperate feeling of being rootless and the search of anchorage, a mooring compel her to belong somewhere and she finds that anchorage in poetry and calls poetry as place. The creation and migration are closely connected because the migration imposes anonymity, loss of identity on the immigrant. Therefore, the immigrant uses the medium of creation to escape from the situation of oblivion of anonymity to ensure the performance in a changing world. The agony of migration made poet to write survive. (32)

House of a Thousand Doors (1988) represents the influence of family in order to create an artistic vision. She shows her relationship with her origins, her home and also her grandmother in "House of a Thousand Doors":

This house has a thousand doors

The sills are cut in bronze

At twilight

As the sun burns down to the Kerala coast

The roof is tiled in red

In dreams

Waves lilt, a silken fan

In grandmother's hands

Shell colored, utterly bare

As the light takes her.

She kneels at each

Of the Thousand Doors in turn

Paying her dues.

Her debt is endless. (1-21)

The sweetness of the homeland is expressed and her words of consolation also be seen in the above lines. In this poem, Meena Alexander tries to seek her identity through the figures of her grandmother Kunju. She wanted to tear herself free from the past. The poem represents the human condition in the chaotic world of today. It represents the pain of crossing borders. A sense of continuity of relationship with home remains uninterrupted and unbroken. The House in this poem is reminiscent of A.K. Ramanujan's “Small Scale Reflections on a Large House" that is at once emblematic of the Indian culture. "House of a Thousand Doors" also signifies that India has importance to both individuality and a feeling of community.

The poem "Muse" reflects the world of personal loss mediated by memory and exile. The composition of poems in the early age saves the poet from burning and she turns her into the molten thing. For instance:

You come to me

A bird shedding gold feathers,

Each one a quill scraping my tympanum

You set a book to my ribs. 


\section{International Journal of Engineering Applied Sciences and Technology, 2020 \\ Vol. 5, Issue 5, ISSN No. 2455-2143, Pages 100-104 \\ Published Online September 2020 in IJEAST (http://www.ijeast.com)}

Night after night I unclasp it

At the mirror's edge

Alphabets flicker and soar.

Write in the light

Of all the languages

You know the earth contains,

You murmur in my ear.

This is pure transport. (25-36)

In 'Muse' Meena Alexander laments the ruin of 'our language' and the sense of having 'no home':

Our language is in ruins

Vowels impossibly sharp

Broken consonants of bone

She has no home.

The storm, poem represents the theme of violence, displacement, ritual order, dislocation and woman's experience of the world as female and immigrant. It represents the memory as a medium and metaphor to reflect the narrative of loss. The poem "Gold Horizon", reflects the childhood memories. This poem reveals the wish of Meena Alexander to return the world of childhood memories. This poem shows her consciousness moving between two worlds, between memory and present day experience, lit by multiple. It represents the landscape of Kerala. In this poem, there are various images which deal with the present and past of the poet:

Place names splinter on my tongue and flee

Allahabad, Tiruvella, Kozhencheri

Khartoum, Nottingham, New Delhi

Hyderabad, New York,

The piece work of sanity stitching

Them into a single

Coruscating geography

(a long drawn breath

In an infant's dream might work)

Ruined by black water in a paddy field. (50-60)

In this poem, the poet shows the wish to return to the world of childhood memories. This poem is truly heart trending.
The poem displays diasporic sensibility. Memory has played a very important role in her creation of poetry. Migrant memory shaped and gave birth to her poems. The images of fireflies, running river, sinking stones, summer flood, paddy field, stumps of tree, herons shows the picture of Kerala:

She waited where the river ran

That summer as the floods began - stones sinking,

Fireflies murmuring in paddy fields.

Heron on stumps of tree the axe planted

Where little else would work

And everywhere mess of water. (1-8)

In the poem "Black River, Walled Garden" represents the various images and symbols shows the past life of poet's childhood. There are many images in this poem. Warm bunches of mangoes on the mango tree, the world of rock and stone, the cradle in the tree, sugarcane stalks, blades of grass, coiled rosebuds, the monsoon clouds in the sky, garden gate, river in spate and gooseberry bush symbolize the childhood places. For instance:

The leaves of the rose tree

Splinter and flee, the garden

Of my childhood returns to the sea.

The piece work of sanity,

The fretwork of desire,

Restive bits and piece edged into place,

Satisfies so little. (177-183)

There are many images are scattered in the poem. The poet shifts herself from the world of reality to the realm of dreams, unfulfilled wishes and longing for childhood memories. Alexander represents the tree of childhood in this poem, "Black River, Walled Garden" (Illiterate Heart):

I swayed in a cradle hung in a tree

And all of the visible world

Walled garden

Black- River - flowed in me. (152-155)

The poem 'Softly My Soul' (1996) shows the poet's longing for childhood memories. There is anguish of loss. The memory of childhood represents the landscape of Kerala. Her experience of exile is translated into the intimate exploration of a connection to both India and America. This poem reflects 


\section{International Journal of Engineering Applied Sciences and Technology, 2020 \\ Vol. 5, Issue 5, ISSN No. 2455-2143, Pages 100-104 \\ Published Online September 2020 in IJEAST (http://www.ijeast.com)}

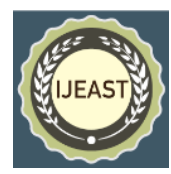

nostalgia for homeland, memories of childhood and also monotonous life of a migrant in the USA.

The lines continue to explore the space of memory in the poem. Night Scene, the Garden reflects the experience of birth of daughter Svati and connects her to past, her mother and grandmother. It shows the trajectory of the history of an ancestral house and its inmates:

Come, ferocious alphabets of flesh

Splinters and raze my page

That out of the dumb

And bleeding part of me

I may claim my heritage. (176-180)

The symbols and metaphors of culture that build Meena Alexander's visionary world are characterized by suffering, pain, loss, memory, hope and possibility of redemption. In this long poem Night - Scene, The Garden, images are very strong:

\section{No man's land \\ No woman's either \\ I stand in the middle of my life. (5-8)}

Deeply interested in a phenomenological study of poetry, she identifies the in - explicable relation of self and the world at large, as one of her major concerns in her creative writing. Her sense of exile is not personal but universal. Her poetry is difficult and highly personal, ambivalent, ambitious and mystically uncertain poetry. Her poetry reflects nature, social life, landscape, war, animal world, violence, history, mythology and the exiled life. It is also interesting because of the intensity of emotions and feelings. Her poetry has the philosophical strength, experimental material and approach. G. Yamini says in the article "Dislocation and Diasporic Consciousness in the poetry of Meena Alexander":

Alexander's poem with their intense lyricism convey the fragmented experience of the traveler, for whom house is both everywhere and nowhere. The landscape she evokes, whether walking on a city street or reading Basho in the Himalayas, hold echoes of otherness.... Alexander's poetry is uniquely attuned to life in a globalized world and serves as an apt guide, bringing us face to face with the power of a single moment and is capacity to evoke the unseen and unheard. Her poetry initiate movements towards a new perception of women and a romantic reconnection with the feminine unconscious an agency of restoration. Generally Alexander distills her poetry out of the present, but the present is constantly inflected by multiple dislocation. (151)

The sense of oppression and resistance has made her poetry of contemporary time and global in significance. Her migratory memory is unceasingly inventive. It also deals with the issues of suppression and burden of female sexuality with reference to Indian woman. The poet represents that her national identity or Indian or Indianness goes unquestioned. But in her search for identity, she brings to her writing a vast range of experience. The reality of this world seems so bitter and this taste is reflecting through her poems. Favas VK writes in the article, "Echoes of Otherness in the selected poems of Meena Alexander":

At the same time as rooting these expressions in the body of her migrant texts, she not only talks the fractures of her selfhood, but also engages into endless scenarios of identity formation. Alexander never isolated herself within the margins of her Indian identity, but rather employs other locales, culture, and in sharp narratives of a 'third space' where self- examination is at the forefront. (113)

A reader who comes across Meena's poetry can appreciate the subtle and mature handling of themes without any bias. She represents the inter connectedness of the past and the present in immigrant imagination. G. Yamini says in the article, "Nostalgia in Meena Alexander's Illiterate Heart":

Alexander mingles her past experience with the mother figure to reveal the complexity of her memories. The present and past coexist in a memory of the mother who is the bloodline of the poet. Her poem reveals the memories of grandmother as powerful ancestral female figure unveiling the hidden layers of poets anguish and despair. By bringing together her past and present her family, community and nation, the poet turns them into piece of writing. Thus, memory becomes the lifeline for the poet, which can pull back the dislocated individual to her real former self. (36)

Her writing also contributes to the continuity of Indian writing in English. Her multicultural abilities create a very interesting effect. In her poetry, she evokes the hunting memories of India. Her poetry swings between the haunting memories of the past and troubled confrontations with the present. It represents her sense of loss and despair of migration. She searches for her own identity in a world that strives to define, the acute sense of loss and nostalgia is reflected in the creative output of Alexander.

\section{CONCLUSION}

Thus, Alexander's poetry represents her old cultural identity through story, myth, language and memory. In her poetry, 
Alexander reflects the vital issues such as ethnicity, identity, belonging and racism whenever she attempts to locate herself within a fractured space between India and America. Alexander mingles her past experience with the mother figure to reveal the complexity of her memories. Her poems convey the fragmented experience of the traveler, for whom home is both everywhere and nowhere.

The tension between desires to belong the inability to do so gave birth to her poetry. Her poetry is a complex interweaving of the Indian and immigrant experiences. Alexander seems to transgress all boundaries with an ease and a struggle to rise above them. Her poetry seems to be a prolonged self- searching. It represents her personal experience, disposition, feelings and judgements. Thus, her writing revolves round the theme of establishing an identity. She finds her better and comfortable world of her own. A. Hessa Alghadeer writes in the article, "Exploring Third Space: Place and Memory in Meena Alexander's Memoir and poems":

Within the layers of the migrant narrative, therefore, Alexander's oeuvre navigates the juncture between social, physical and psychic sites of her world. In effect, the experience of dwelling on the borders of a multicultural metropolis like the city of New York, serves as Alexander's muse inspiring a wide range of remarkable poems. (87)

\section{REFERENCE}

(1) Alghadeer, Heesa A. (2013). "Exploring Third Space: Place and Memory in Meena Alexander's Memoir and Poems", International Journal of Humanities and Social Science, Vol.3 No.20, December 2013, www.ijhssnet.com>journals> vol3-N.... (p.86).

(2) Alexander, Meena. (1988). House of a Thousand Doors, Three Continent Press.

(3) ---. (2003). Illiterate Heart. Northwestern University Press.

(4) ---. (1992). Night-Scene: The Garden. Red Dust.

(5) ---. (1996). River and Bridge. Toronto South Asian Review Press.

(6) ---. (1989). The Storm: A Poem in five parts. Red Dust.

(7) Yamini. G. (2015). "Dislocation And Diasporic Consciousness In the Poetry of Meena Alexander". Asia Pacific Journal of Research, Vol.1, Issue 25, <apjor.com> downloads>0205201519 